\title{
The Enzymatic Decolorization of Textile Dyes by the Immobilized Peroxidase from Chard Leaves (Beta vulgaris Subspecies cicla)
}

\author{
Esma Hande Alici ${ }^{1}$, Gulnur Arabaci ${ }^{1}$ \\ ${ }^{1}$ Department of Chemistry, Faculty of Art and Science, Sakarya University \\ TR-54050, Sakarya, Turkey \\ ealici@ sakarya.edu.tr; garabaci@sakarya.edu.tr
}

\section{Extended Abstract}

Water-pollution and its control is one of the major interests of scientific research. Effluent discharge from textile, paper, cosmetics, leather, food and dyestuff industries to neighbouring water bodies is currently causing significant health concerns to environmental regulatory agencies [1]. Synthetic dyes are used in industry due to their features like high stability to light and washing and resistance to microbial attack. Therefore, these dyes are not readily degradable and cannot be removed from the effluent by the conventional wastewater treatment methods, easily. Some physicochemical methods such as coagulation, ultrafiltration, adsorption by activated carbon, oxidation, reduction, precipitation, electrochemical treatment, and ion-pair extraction are generally used for treatment of textile and dyestuff industrial wastes having different dyes. However, these methods are not very suitable because of high costs, low efficiency, toxic pollutants, disposal problems and inapplicability to a wide variety of dyes [2].

Biological treatments are most suitable and widely used methods as a result of their cost effectiveness, ability to produce less sludge, and eco-friendly nature. Enzymatic decolorization is a biological method that uses enzymes for treatment of industrial wastes containing dyes. Azoreductases, Laccases, Peroxidases (Manganese peroxidase, Lignin peroxidase, etc.), and Polyphenol oxidases are promising and well-known enzymes in the decolorization and degradation of industrial dyes [3].

In this study, the performance of peroxidase enzyme (POD) from chard leaves regarding the decolorization of various dyestuffs was evaluated. At first, POD enzyme was extracted from chard leaves (Beta vulgaris Subspecies cicla). A natural and non-polluting source, chard leaves crude extract, was used as enzyme solution. The crude extract was prepared by homogenization. Then, the crude enzyme was immobilized on calcium alginate beads. Immobilization was necessary to overcome the high cost of the enzyme through reusability. Finally, the decolorization of textile dyes was determined spectrophotometrically for free and immobilized enzyme.

\section{References}

[1] I. M. Banat, P. Nigam, D. Singh, R. Marchant, "Microbial decolorization of textile-dye-containing effluents: A Review," Bioresource Technology, vol. 28, pp. 217-227, 1996.

[2] T. S. Shaffiqu, J. Jegan Roy, R. Aswathi Nair, T. Emilia Abraham, "Degradation of textile dyes mediated by plant peroxidases," Applied Biochemistry and Biotechnology, vol. 102-103, pp. 315-326, 2002.

[3] R. Lakhan Singh, P. Kumar Singh, R. Pratap Singh, "Enzymatic decolorization and degradation of azo dyes - A Review," International Biodeterioration \& Biodegradation, vol. 104, pp. 21-31, 2015. 